\title{
Physicochemical and Functional Properties of Flour from the Wild Edible Mushroom Termitomyces heimii Natarajan Harvested in Côte d'Ivoire
}

\author{
Edmond Ahipo Due ${ }^{1^{*}}$, Djary Michel Koffi ${ }^{2}$, Yolande Dogore Digbeu ${ }^{1}$
}

${ }^{1}$ Laboratory of Biochemistry and Food Technology, Nangui Abrogoua University, 02 BP 801, Abidjan 02, Cote D'Ivoire. ${ }^{2}$ Laboratory of Biotechnology, Felix Houphouët-Boigny University, 22 BP 582 Abidjan 22, Côte d'Ivoire.

\section{A R T I C L E I N F O}

Article history:

Received 24 April 2016

Accepted 21 July 2016

Available online, ISSN: 2148-127X

Keywords:

Proximal composition Functional properties Wild edible mushroom Termitomyces heimii Flour

${ }^{*}$ Corresponding Author:

E-mail: ahipoedmond@yahoo.fr \begin{abstract}
A B S T R A C T
In Sub-Saharan Africa, especially, in Côte d'Ivoire, the wild edible mushroom Termitomyces heimii Natarajan is the most prized and widely consumed for different reasons such as taste, flavour, attractiveness, uses as substitutes for meat or fish and medicinal values. The present study was aimed at evaluating the proximate composition and functional properties of $T$. heimii flour for further food products formulation. Fresh mushroom $T$. heimii were obtained from the market of Aboisso $\left(5^{\circ} 28^{\prime} 06^{\prime \prime} \mathrm{N}\right.$ and $3^{\circ} 12^{\prime}$ $25^{\prime \prime} \mathrm{W}$ ) in Côte d'Ivoire. The fresh mushrooms were dried and ground to obtain the crude flour. Chemical composition and functional properties were investigated using standard methods. The chemical composition revealed that it contains crude protein about $23.75 \%$, crude fat $3.58 \%$, moisture $11.59 \%$, ash $7.40 \%$, total carbohydrate $54.70 \%$ and energy value of $345.90 \mathrm{kcal} / 100 \mathrm{~g}$. These results suggest that $T$. heimii can be used in human diet to prevent undernourishment due to protein. Furthermore, the low fat content suggest that it would be an ideal food for obese persons and useful in preventing hypertension and hypercholesterolemia. The functional properties showed that it has high bulk density and water absorption capacity with values of $0.737 \mathrm{~g} / \mathrm{mL}$ and $315.15 \pm 45.74 \%$ respectively. This flour exhibited also good foaming properties. All these characteristics make it suitable as good thickeners in food products, useful in foods such as bakery products which require hydration and attractive for products like cakes or whipping topping where foaming is important. The mushroom $T$. heimii could be utilized for making some low-fat foodstuffs and snacks with considerable protein content. The mushroom flour shows good functional characteristics for use in many food industries.
\end{abstract}

\section{Introduction}

Wild edible fungi are a distinct group of organisms which include species with large and visible fruiting bodies (macrofungi). The best known examples of macrofungi are the mushrooms (Boa, 2004). Mushrooms are an important source of food and income in both developing and developed countries (Hosford et al., 1997; Wong et al., 2001; Boa, 2004). In most countries of the world, they are known and consumed in many households. In rural areas where mushrooms are abundant, most people collect them for home consumption as well as for extra income (Koné et al., 2013). Furthermore, indigenous peoples are utilizing mushroom for the treatment of different type of diseases and also as an aphrodisiac and tonic (Devkota, 2006). Different types of edible mushrooms are cultivated on large scale for commercial use and many more species of mushrooms grow wildly in nature which has much nutritional and medicinal value (Boa, 2004).

Mushrooms can provide balancing diet compounds in sufficient quantities for human nutrition. They are rich in protein and have considerable value as a source of dietary fibre because of both their high fibre content and their unique fibre composition (Chittaragi and Naika, 2014). Mushrooms are low in fat and energy and make a useful contribution to mineral and vitamin intake, particularly the $\mathrm{B}$ vitamins and vitamins $\mathrm{D}$ and $\mathrm{K}$, and in some cases vitamins A and C (Sadler, 2003; Sanmee et al., 2003). In terms of current dietary advice, $80 \mathrm{~g}$ of macrofungi represent one portion of vegetables (De Román et al., 2006).

Many mushroom species of the genus Termitomyces (Lyophyllaceae), which grow abundantly in termite nests, have been identified as wild edible mushrooms with high nutritive value (Chakraborty et al., 2006; Chandra et al., 2007). Termite mushrooms, Termitomyces sp. are giant mushrooms that emerge from the base of the termite mounds during the rainy season. They cannot be currently cultivated as their cultivation is difficult because of the very specific condition under which it grows in nature (Hildén et al., 2013). In Sub-Saharan Africa, fruit bodies of this genus are the most appreciated edible mushrooms and they are also valuable because they add flavour to bland staple foods and have a delicious taste. Termitomyces fruit bodies were found to stand alone as a 
meal and being used as supplement or alternative to meat or fish by rural people since they are less expensive. The big town consumers usually mixed these mushrooms with meat or fish in their daily diet, considering it a side dish only (Malek et al., 2012). In addition, these fungi have potential therapeutic uses in blood pressure and blood lipid regulation, the immune response, apoptosis and infection (Tidke and Rai, 2006; García-Lafuente et al., 2011).

In Côte d'Ivoire, the local people call them "termite mushrooms" meaning "mushrooms produced or cultivated by termites". Their vernacular names are n'glô in Baoulé and n'kôkrô in Abbey (Koné et al., 2013). Especially, the species Termitomyces heimii Natarajan is highly prized due to its unique taste unlike many other cultivated mushrooms. The present paper focuses on the proximate composition and the functional properties of flour from the mushroom T. heimii harvested in Côte d'Ivoire. It is well know that functional properties of foods are intrinsic physicochemical characteristics, which affect the behaviour of proteins in food systems during processing, manufacturing, storage and preparation (Onimawo and Akubor, 2005). Such functional properties could be used to determine the suitability or otherwise of this mushroom as food additive.

\section{Materials and Methods}

\section{Mushroom Collection and Preparation of Sample}

Fresh mushroom $T$. heimii were obtained from the market of Aboisso ( $5^{\circ} 28^{\prime} 06^{\prime \prime} \mathrm{N}$ and3 ${ }^{\circ} 12^{\prime} 25^{\prime \prime} \mathrm{W}$ ) in Côte d'Ivoire. After collection, mushrooms were placed in a cooler with ice to keep their freshness and then transported to the laboratory for flour preparation. Fresh mushrooms were cleaned to distilled water then, sorted and free from any kind of waste, drained, and1 $\mathrm{kg}$ was dried at $65^{\circ} \mathrm{C}$ in an oven for $72 \mathrm{~h}$. Dried mushrooms were ground using a blender to obtain the crude flour.

\section{Proximate Composition}

The moisture content was determined by drying in an oven at $105^{\circ} \mathrm{C}$ during $24 \mathrm{~h}$ to constant weight (AOAC, 1995). The crude protein content was calculated from nitrogen contents $(\mathrm{N} \times 6.25)$ obtained using the Kjeldahl method by AOAC (1995). The crude fat content was determined by continuous extraction in a Soxhlet apparatus for $8 \mathrm{~h}$ using hexane as solvent (AOAC, 1995). The total ash content was determined by incinerating in a furnace at $550^{\circ} \mathrm{C}(\mathrm{AOAC}, 1995)$. The crude fibre content was determined by taking about $3.0 \mathrm{~g}$ sample as portion of carbohydrate that resisted sulfuric acid (1.25\%) and $\mathrm{NaOH}(1.25 \%)$ digestion followed by sieving $(75 \mu \mathrm{m})$, washing, drying and ignition to subtract ash from fiber (AOAC, 1995). The carbohydrate content was determined by deference that is by deducting the mean values of other parameters that were determined from 100 . Therefore $\%$ carbohydrate $=100-(\%$ moisture $+\%$ crude protein $+\%$ crude fat + crude fibre $+\%$ ash $)$.

\section{Functional Properties}

Water absorption capacity (WAC): The water absorption capacity was evaluated according to Phillips et al. (1988) method. Two gram of flour was weighed into a centrifuge tube and $50 \mathrm{~mL}$ distilled water added. The content of the centrifuge tube was shaken for $30 \mathrm{~min}$ in a KS 10 agitator. The mixture was kept in a water-bath $\left(37^{\circ} \mathrm{C}\right.$ ) for $30 \mathrm{~min}$ and centrifuged (Ditton LAB centrifuge, UK) at $5000 \mathrm{rpm}$ for $15 \mathrm{~min}$. The resulting sediment (M2) was weighed and then dried at $105^{\circ} \mathrm{C}$ to constant weight (M1). The WAC was then calculated as follows:

$$
\operatorname{WAC}(\%)=\frac{\mathrm{M} 2-\mathrm{M} 1}{\mathrm{M} 2} \times 100
$$

Oil absorption capacity: For the oil absorption capacity, the method of Beuchat(1977)was used. One gram of flour sample was mixed with $10 \mathrm{~mL}$ of oil for 30 min in a mixer (Vari-whirl-mixing control set at fast speed). The sample was then allowed to stand at room temperature for $30 \mathrm{~min}$. It was then centrifuged at 5000 rpm for $30 \mathrm{~min}$, using a spinner (Ditton LAB centrifuge, UK) and the volume of the supernatant noted in a $10 \mathrm{~mL}$ graduated cylinder. The density of the oil was determined too. The volume of oil absorbed was multiplied by the density of the oil to determine the weight of oil so absorbed.

$$
\mathrm{OAC}(\%)=\frac{(\mathrm{V} 1-\mathrm{V} 2) \times \mathrm{D}}{\mathrm{W}} \times 100
$$

Where:

$\mathrm{V} 1$ = Initial volume of oil used

V2 = Volume remaining (not absorbed)

$\mathrm{D}=$ Density of the oil used

$\mathrm{W}=$ Weight of sample

Foaming capacity and foam stability: The foaming capacity (FC) and stability (FS) of flour were studied according the method of Coffman and Garcia (1977). Three (3) g of flour was transferred into clean, dry and graduated $(50 \mathrm{~mL})$ cylinders. The flour sample was gently levelled and the volumes noted. Distilled water $(30 \mathrm{~mL})$ was added to the sample; the cylinder was swirled and allowed to stand for $120 \mathrm{~min}$ while the change in volume was recorded every $15 \mathrm{~min}$.

$$
\begin{gathered}
\mathrm{FC}(\%)=\frac{\mathrm{V}_{\mathrm{T}}-\mathrm{V}_{0}}{\mathrm{~V}_{0}} \times 100 \\
\mathrm{FS}(\%)=\frac{\mathrm{FC}}{\mathrm{FC}_{0}} \times 100
\end{gathered}
$$

Where $\mathrm{V}_{0}$ is the original volume of sample $(\mathrm{mL}), \mathrm{Vt}$ is the total volume after different times $(\mathrm{mL})$ and $\mathrm{FC}_{0}$ is the foam capacity $(\mathrm{FC})$ at $0 \mathrm{~min}$. 


\section{Bulk Density Measurement}

The volume and bulk density were determined according to the modified method of Okezie and Bello (1988), by pouring $2 \mathrm{~g}$ of flour into a $10 \mathrm{~mL}$ measuring cylinder, and then holding the cylinder on a vortex vibrator for $1 \mathrm{~min}$ to obtain a constant volume of the sample. The volume of the sample was recorded against the scale on the cylinder. The bulk density value was calculated as the ratio of mass of the powder and the volume occupied in the cylinder.

\section{Determination of Wettability}

The method described by Onwuka (2005) was adopted. One gram $(1 \mathrm{~g})$ of flour sample was measured into a $10 \mathrm{~cm}^{3}$ measuring cylinder. The cylinder was inverted at $10 \mathrm{~cm}$ above the water contained in $600 \mathrm{~mL}$ beaker. The finger was used to close the cylinder disallowing the flour sample from falling. By removing the finger and giving the cylinder a gentle tap, the flour sample was discharged into the water surface. The time taken by the sample to get completely wet was recorded as the time of wettability.

\section{Results and Discussion}

\section{Proximate Composition}

Table 1 presents biochemical properties of the mushroom T. heimii. As regards these results, the moisture content was found to be $11.59 \%$. This value is similar to that of mushroom Omphalotus olearius $(11.1 \%)$ reported by Aremu et al. (2009). However, it is higher than the value of Lentinus trigrinus (9.20\%) previously reported by Adejumo and Awosanya (2005). This is an indication that mushrooms are highly perishable because high moisture content promotes susceptibility to microbial growth and enzyme activity which accelerates spoilage.

The high ash content $(7.40 \%)$ of $T$. heimii indicates that this fungus is good source of mineral elements. Indeed, this value is higher compared to those of several wild and cultivated mushrooms of Ghana such as $T$. robustus (6.21\%), Lentinus squarrosulus (5.60\%) and Auricularia auricula (3.05\%) (Obodai et al., 2014). The ash content of the sample is of nutritional importance as a previous report indicated that when leaves or vegetables are to be used as food for humans, they should contain about 3.0\% ash (Pivic and Butler, 1977).

As regards proteins, edible mushrooms have been shown to have higher protein content, on a mass basis, than other many plant foods such as leafy vegetables, soybeans and maize (Teffo et al., 2007; Zoro et al., 2014). The studied edible mushroom, with a protein content of $23.75 \%$, can therefore be ranked as protein rich food for both humans and livestock thus can support the protein need of the poor peasants and solve the problem of malnutrition. Especially in developing countries, it could be used as good substitute proteins for malnourished children suffering from kwashiorkor (a protein deficiency condition).
The fat content obtained $(3.58 \%)$ is very lower than those reported by Adejumo et al. (2015) for Termitomyces robustus (9.07\%), Volvariella volvacea (10.60\%), Termitomyces microcarpus (13.81\%) and Pleurotus ostreatus $(15.38 \%)$. This low fat content confirm that $T$. heimii would be an ideal food for obese persons and it would be useful in preventing hypertension and hypercholesterolemia, as suggest by Tidke and Rai (2006). It is obvious that edible mushrooms can be used for making some low-fat foodstuffs and snacks, but their lipid levels were too low to be a practical raw material for making edible oil.

The crude protein content of $T$. heimii which was $23.75 \%$ is in the range of values reported for many edible mushrooms in Nigeria (Adejumo et al., 2015).Therefore, T. heimii can be ranked as protein-rich food for both humans and livestock thus can support the protein need of all fringes of the population especially vulnerable populations such as pregnant women, children and the poor peasants and solve the problem of malnutrition.

The carbohydrate content of the studied edible mushroom was relatively high, with value of $47.66 \%$. Similar values which ranged from 30.20 to $55 \%$ have been reported in some edible mushrooms such as Termitomyces sp., Russula sp. and Pleutorus tuberregium in South-Eastern Nigeria (Ijioma et al., 2015).

The low energy levels provided by the edible mushroom T. heimii (less than $400 \mathrm{kcal} / 100 \mathrm{~g} \mathrm{DW}$ ) give only about $17.30 \%$ of the daily energy intakes recommended for a $70 \mathrm{~kg}$ person. It is well know that the energy content is affected by the proportion of fat, protein and carbohydrate in the edible mushrooms. The present results agreed that edible mushrooms can be used as a source of low energy diet (Wong, 2002).

Table 1 Physicochemical properties of the mushroom T.heimii.

\begin{tabular}{l|r}
\multicolumn{1}{c|}{ Parameters } & Values (\%) \\
\hline Moisture & $11.59 \pm 0.07$ \\
Proteins & $23.75 \pm 0.04$ \\
Carbohydrates & $47.66 \pm 0.05$ \\
Crude fibre & $6.02 \pm 0.04$ \\
Fats & $3.58 \pm 0.01$ \\
Ash & $7.40 \pm 0.06$ \\
Energy value (kcal/100 g) & $345.90 \pm 0.07$ \\
\hline
\end{tabular}

Values are mean \pm standard deviation of three measurements $(n=3)$

\section{Functional Properties}

The functional properties of flour from $T$. heimii were summarized in table 2 . The bulk density of the studied mushroom flour was found to be $0.74 \mathrm{~g} / \mathrm{mL}$. This value is higher than those of flours from Ganoderma spp. (0.23 $\mathrm{g} / \mathrm{mL})$, Omphalotus olearius $(0.39 \mathrm{~g} / \mathrm{mL})$ and Hebeloma mesophaeum (0.41 g/mL) (Aremu et al., 2009), suggesting that it would serve as good thickeners in food products. Indeed, higher bulk density is desirable for the greater ease of dispersibility and reduction of paste thickness which is an important factor in convalescent and child feeding (Padmashree et al., 1987). 
Table 2 Functional properties of mushroom T.heimii flour

\begin{tabular}{l|c}
\hline \multicolumn{1}{c|}{ Parameters } & Values \\
\hline Bulk density (g/mL) & $0.74 \pm 0.02$ \\
Wettability (s) & $57.68 \pm 2.04$ \\
Foaming capacity (\%) & $16.67 \pm 0.00$ \\
Water absorption capacity (\%) & $315.15 \pm 45.74$ \\
Oil absorption capacity (\%) & $125.25 \pm 30.05$ \\
\hline
\end{tabular}

Values are mean \pm standard deviation of three measurements $(n=3)$

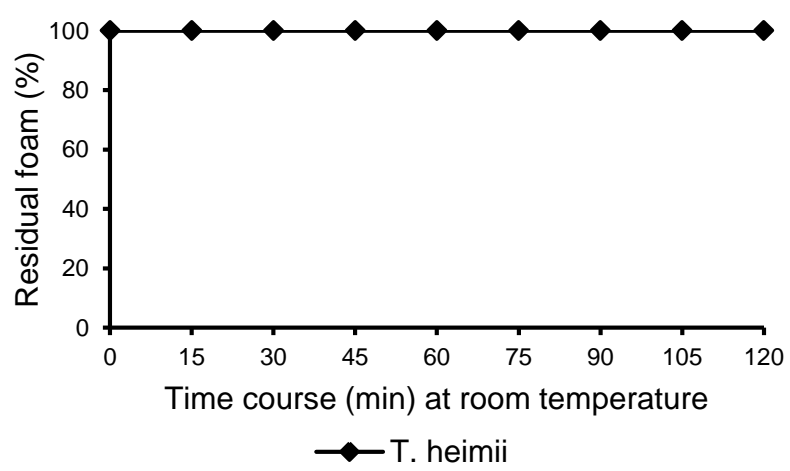

Figure 1 Foam stability of flour from the wild edible mushroom T.heimii. Bars represent $\pm \mathrm{SE}$.

The results showed that the studied flour wet very quickly (57.68 s). This might be due to very low fat content of this mushroom. According to Akpossan et al. (2015), defatting greatly influences the wettability. Moreover, wettability of proteins is affected by surface polarity, topography, texture, area and by the size and microstructure of the protein particles (Hagerdal and Lofqvist, 1978).

As regards water absorption capacity (WAC) obtained in this study (315.15\%), it was higher than those reported for the Jackfruit seed flour (25\%) (Ocloo et al., 2010), African yam bean (17\%) (Eke and Akobundu, 1993) and for Oryctes owariensis (220.33\%) (Assiélou et al., 2015). The results obtained are however similar to those of flours from three mushrooms reported by Aremu et al. (2009). This indicates that flour from $T$. heimii is highly hydrophilic and it would be useful in foods such as bakery products which require hydration to improve handling characteristics (Barbut, 1999). The difference in protein structure and the presence of different hydrophilic carbohydrates might be responsible for variation in the WAC of the flour. Indeed, flours with high WAC have more hydrophilic constituents such as polysaccharides (Aremu et al., 2009).

The oil absorption capacity (OAC) was $125.25 \%$. This value was found to be much lower than those reported for flours from Ganoderma spp., $O$. olearius and $H$. mesophaeum, ranging from $450-480 \%$ (Aremu et al., 2009). This corroborates the low fat content obtained in this study, confirming that the studied mushroom would be an ideal food for obese persons and useful in preventing cardiovascular diseases.

Concerning foams, it is noteworthy that they are used to improve the texture, consistency and appearance of foods (Akubor and Chukwu, 1999). The flour from $T$. heimii shows foaming capacity of $16.67 \%$ which is higher than values reported for pearl millet flour and quinoa flour (11.30 and 9\% respectively) (Oshodi et al., 1999). However, this value is lower than those reported for eleven Pleurotus mushrooms (ranging from $32-64 \%$ ) (Wong, 2002). Foamability is reported to be related to the amount of solubilised proteins (Narayana and Narasinga, 1982) and the amount of polar and non-polar lipids in a sample (Nwokolo, 1985). Furthermore, the studied flour showed high foaming stability of $100 \%$ (Figure 1). This value is greater than those reported for mushroom flours from Nigeria (about $50 \%$ )(Aremu et al., 2009) and Jackfruit flour (33\%) (Ocloo et al., 2010). Consequently, flour from $T$. heimii seems to be attractive for products like cakes or whipping topping where foaming is important, since it is well know that foam stability (FS) refers to the ability of a foam to retain its maximum volume over time and it is usually determined by measuring the rate of leakage of fluid from the foam (Kinsella, 1979).

\section{Conclusion}

To sum up this report, it may be concluded that the mushroom $T$. heimii is a good source nutrients mainly consist of proteins and carbohydrates indicating that $T$. heimii can be used in human diet to prevent undernourishment due to protein. Contrarily, it was found to be low-fat foodstuffs. This implies that $T$. heimii can be used in human diet to prevent undernourishment due to protein and to prevent obesity and cardiovascular diseases. As far as concerned functional properties, the studied mushroom flour showed high bulk density and water absorption capacity and good foaming characteristics indicating its usefulness as good thickeners in food products, in foods such as bakery products which require hydration and for products like cakes or whipping topping where foaming is important.

\section{References}

Adejumo TO, Coker ME, Akinmoladun VO. 2015. Identification and Evaluation of Nutritional Status of some Edible and Medicinal Mushrooms in Akoko Area, Ondo State, Nigeria.Int J Cur Microbiol App Sci. 4 (4): 1011-1028.

Adejumo TO, Awosanya BO. 2005. Proximate and mineral composition of edible mushroom species from south western Nigeria. Afri J Biotechnol.4(10): 1084-1087.

Akpossan RA, Digbeu YD, Koffi DM, Kouadio JPEN, Due EA, Kouame PL. 2015. Protein Fractions and Functional Properties of Dried Imbrasia oyemensis Larvae Full-Fat and Defatted Flours. Inter J Biochem Res Rev. 5(2):116-126.

Akubor PI, Chukwu JK. 1999. Proximate composition and selected functional properties of fermented and unfermented African oil bean (Pentacle thramacrophylla) seed flour. Plant Food Hum Nutr.54:227-238.

AOAC. 1995. Official Methods of Analysis of the Association of Official Analytical Chemists, 16th ed. Virginia. U.S.A.

Aremu MO, Basu SK, Gyar SD, Goyal A, Bhowmik PK, Datta BS 2009. Proximate Composition and Functional Properties of Mushroom Flours from Ganoderma spp., Omphalotus olearius (DC.) Sing. And Hebeloma mesophaeum (Pers.) Quél. Used in Nasarawa State, Nigeria. Mal J Nutr.15(2):233-241. 
Assiélou B, Due EA, Koffi MD, Dabonné S, Kouamé PL. 2015. Oryctes owariensis Larvae as Good Alternative Protein Source: Nutritional and Functional Properties. An Res Rev Biol. 8(3): 19.

Barbut S.1999. Determining water and fat holding.In G. M. Hall (Ed.), Methods of testing protein functionality. New York: Blackie Academic and Professional. Pp 186-225.

Beuchat LR. 1977. Functional and electrophoretic characteristics of succinylated peanut flour protein. J Agric Food Chem.25:258261.

Boa E. 2004. Wild Edible Fungi.A Global Overview of Their Use and Importance to People.Non-wood Forest Products Series no. 17. Rome: FAO.

Chakraborthy I, Mondal S, Rout D, Syed S. 2006. A water insoluable (1-3)- $\beta$-glucan from alkaline extract of an edible mushroom Termitomyces eurhizus.Carbohydr Res.341:29902993.

Chandra K, Ghosh K, Roy SK, Mondal S, Maiti D, Ojha AK, Das D, Mondal S, Islam SS. 2007. A water-soluble glucan isolated from an edible mushroom Termitomyces microcapus. Carbohydr Res. 342: 2484-2489.

Chittaragi A, Naika R. 2014. Study on primary biochemical and physicochemical properties of Ganoderma sinense from forest regions of Shimoga (D), Karnataka. Arch AppSci Res. 6 (4):103-108.

Coffman CW, Gracia VV. 1977. Functional properties of amino acid content of a protein isolate from mung bean flour. J Food Technol. 12: 473-484.

De Román M, Boa E, Woodward S. 2006. Wild-gathered fungi for health and rural livelihoods. Proc Nutr Soc. 65: 190-197

Devkota S. 2006. Yarsagumba; Traditional utilization in Dolpa district, Western Nepal.Our Nature.IntBiol J. 4:48-52.

Eke OS, Akobundu ENT. 1993. Functional properties of African yam bean (Sphenostylis stenocarpa) seed flour as affected by processing. Food Chem.48:337-340.

García-Lafuente A, Moro C, Villares A, Guillamón E, Rostagno MA, D'Arrigo M, Martínez JA. 2011.Mushrooms as a source of anti-inflammatory agents. Am J Comm Psychol.48: 125-141.

Hagerdal B, Lofqvist B. 1978. Wettability and surface pressure of myoglobin treated with acetone. J Food Sci.43:27-30.

Hildén K, Mäkelä M, Lankinen P, Lundell T. 2013. Agaricus bisporus and related Agaricus species on lignocellulose: Production of manganese peroxidase and multicopper oxidases. Fungal Gen Biol. 55: 32-41.

Hosford D, Pilz D, Molina M, Amaranthus M. 1997.Ecology and Management of the Commercially Harvested American Matsutake Mushroom. General Technical Report PNW-GTR412. Portland, OR: US Department of Agriculture, Forest Service, Pacific Northwest Research Station.

Ijioma BC, NgozilC, Ngozi OC, Okafor DC. 2015. Nutritional composition and some anti-nutritional factors of three edible mushroom species in South Eastern Nigeria. Eur J Food SciTechnol. 3(2): 57-63.

Kinsella JE. 1979. Functional properties of soy proteins. J Am Oil Chem Soc.56: $242-258$.

Koné NA, Yéo K, Konaté S, Linsenmair KE. 2013. Socioeconomical aspects of the exploitation of Termitomyces fruit bodies in central and southern Côte d'Ivoire: Raising awareness for their sustainable use. J ApplBiosci. 70:5580-5590
Malek SNA, Kanagasabapathy G, Sabaratnam V, Abdullah N, Yaacob H. 2012. Lipid components of a Malaysian edible mushroom, Termitomyces heimii Natarajan. Int J Food Prop. 15:809-814,

Narayana K, Narasinga RMS. 1982. Functional properties of raw and heat processed winged bean flour. J Food Sci. 47: 15341538.

Nwokolo E. 1985. Nutritional quality of the seeds of the African breadfruit (Treculia Africana Decne). Trop Sci. 27: 39 - 47.

Obodai M, Ferreira ICFR, FernandesÂ, Barros L, Mensah DLN, Dzomeku M, Urben AF, Prempeh J,Takli RK. 2014. Evaluation of the chemical and antioxidant properties of wild and cultivated mushrooms of Ghana. Molecules.19: 19532-19548.

Ocloo FCK, Bansa D, Boatin R, Adom T, Agbemavor WS. 2010. Physico-chemical, functional and pasting characteristics of flour produced from Jackfruits (Artocarpus heterophyllus) seeds. AgrBiol J North Am.15:903-908.

Okezie BO, Bello AB. 1988. Physicochemical and functional properties of winged bean flour and isolate compared with soy isolate. J Food Sci. 53:450-454.

Onimawo IA, Akubor PI. 2005. Functional properties of food. In: Food Chemistry, integrated approach with biochemical background. Ambik Press Ltd, Benin City.208-221.

Onwuka GI. 2005. Food Analysis and Instrumentation. Theory and Practice. Naphtali Prints, Lagos, Nigeria. Pp 133-137.

Oshodi AA, Ogungbenle HN., Oladimeji MO. 1999. Chemical composition, nutritionally valuable minerals and functional properties of Benniseed, pearl millet and quinoa flours. Int $\mathbf{J}$ Food SciNutr. 50: $325-331$.

Padmashree TS, Vijayalakshmi L, Puttaraj S. 1987. Effect of traditional processing on the functional properties of cowpea (Vigna Catjang) flour. Journal of Food Science and Technology.24:221-224.

Phillips RD, Chinnan MS, Branch AL, Miller J, Mcwatters KH. 1988. Effects of pre-treatment on functional and nutritional properties of cowpea meal. J Food Sci. 53(3):805-809.

Pivic NW, Butler JB. 1977. A simple unit leaf. Proc Nutr Soc.12:36: 136.

Sadler M. 2003.Nutritional properties of edible fungi.Nutr Bull. 28: $305-308$.

Sanmee R, Dell B, Lumyong P, Izumori K,Lumyong S. 2003. Nutritive value of popular wild edible mushrooms from northern Thailand. Food Chem. 82: 527-532.

Teffo LS, Toms RB, Eloff JN. 2007. Preliminary data on the nutritional composition of the edible stink-bug, Encosternum de le gorguei Spinola, consumed in Limpopo province, South Africa. South Afr J Sci.103: 434-436.

Tidke G, Rai M. 2006. Biotechnological potential of mushrooms: drugs and dye production. Med. Mushr.8:351-360.

Wong JLG, Thornber K, Baker N. 2001. Resource Assessment of Non-wood Forest Products. Experience and Biometric Principles.Non-wood Forest Products Series no.13. Rome: FAO.

Wong WC. 2002. Chemical composition, functional properties and nutritional values of two groups of mushrooms including eleven edible Pleurotus mushrooms and fifteen other lesser-known edible ones. Thesis of the Chinese University of Hong Kong.182 p.

Zoro AF, Zoue LT, Niamke LS. 2014. Evaluation of nutritive and antioxidant properties of blanched leafy vegetables consumed in western Côte d'Ivoire. J Fac Food Eng. 13: 99-108. 